\title{
Assessment criteria of competence formation of organizers in the educational process of the agrarian university in the field of using information and communication technology
}

\author{
E.R. Gazizov ${ }^{1, *}, A . R$. Gazizov $^{2}, N . G$. Kiseleva $^{1}$, and A.N. Zinnatullina ${ }^{1}$ \\ ${ }^{1}$ Kazan State Agrarian University, 420015 Kazan, Russia \\ ${ }^{2}$ Don State Technical University, 344000 Rostov-on-Don, Russia
}

\begin{abstract}
The article defines the evaluation criteria for the formation of the competence of the organizers of the educational process at the Agrarian University in the use of information and communication technology tools. It is shown how to estimate this level. Measurable indicators of evaluation criteria are highlighted and methods for measuring these indicators are disclosed. The scale of competence levels of the organizers in the educational process at the Agrarian University in the use of information and communication technology tools is given.
\end{abstract}

\section{Introduction}

The current stage of development of society is characterized by the active use of information and communication technology (ICT) in many areas of human activity, including education. The process of informatization of education initiates the search for ways to realize the potential of ICT tools in order to increase the efficiency of the educational process and develop the skills of students to use these tools in their professional activities.

At the same time, there are new requirements for professional training in the use of ICT tools, including the organizers of the educational process of the Agrarian University (Vice-Rector for Academic Affairs, Head of the Educational Department, Heads of Educational Institutions, Deans of Faculties, their deputies, Head of Departments).

Questions of the theory and methodology of teaching pedagogical workers in the system of higher professional education in the use of ICT tools are considered in scientific and pedagogical research by the authors of this article [1], as well as by such authors as Kovalenko M.I., Kozlova O.A., Lavinoy T.A., Robert I.V. [2-6]. However, in these works, the features of preparing the organizers of the educational process of an agricultural university to use ICT tools in their professional activities were not fully considered.

\section{Methods}

The analysis of the Federal State Educational Standards for Higher Education in the areas of bachelor's studies "Economics", "Management", "State and Municipal
Management", "Quality Management" [7] at the Institute of Economics of Kazan State Agrarian University showed that professional competences in the use of ICT tools are formed in the framework of the study of the discipline "Information technology". This discipline belongs to the basic part of the mathematical and natural science cycle and, obviously, its volume is clearly not enough to form competencies in the use of ICT tools.

The lack of time and the volume of material in the study of this discipline predetermines the relevance of the development of theoretical aspects and methodological approaches to the formation of the competence of the organizers of the educational process at the agricultural university using ICT tools. This will affect organizational, managerial, technological and information-analytical activities as the main directions of using ICT tools in the professional activities of this category of teaching staff.

There are several evaluation criteria for the formation of competence of the organizers of the educational process of the agricultural university in the use of ICT tools in the process of improving the skills of this category of teachers, focused on the formation of this type of competence.

This follows from the analysis of federal laws and regulatory documents of the Ministry of Education and Science of the Russian Federation, which regulate the educational process of the Agrarian University. This also includes the analysis of the Federal State Educational Standard of Higher Education in the areas of training bachelors "Economics", "Management", "State and Municipal Management", "Quality Management", and qualification requirements for education workers of the Russian Federation in the field of possession of ICT funds [8].

* Corresponding author: gazizov.e@bk.ru 


\section{Results}

We list the resulting evaluation criteria. The first criterion is the search for information and the development of new software products. The second criterion is the use of technology for processing numerical and textual information in the educational process. The third criterion is the creation of didactic materials. The fourth criterion is the creation of traditional teaching aids. The fifth criterion is the method of using electronic educational resources on a problem-modular basis (presentations on the project topic). The sixth criterion is the selection of content for electronic educational resources. The seventh criterion is the use of presentation technology in the organization of educational activities. The eighth criterion is the organization of the virtual space of professional activity.

Evaluation criteria for the development of competence of the organizers of the educational process of the agricultural university of the use of ICT tools in the context of the measured indicators reflecting them and methods for evaluating these indicators when organizing training for an additional professional program (advanced training program) are presented in Table 1 [9].

The following methods were used to measure indicators:

1. Assessment of the fulfillment of the control task (the teacher gives the general task in the classroom to the students and at the end of the class evaluates the completed task) - the task is evaluated by the teacher in the range from 1 to 5 points.

2. Assessment of students' independent work (students perform the task given by the teacher at home, and in class the teacher evaluates the task done) - the task is evaluated by the teacher in the range from 1 to 5 points.

3. Oral poll of students - the answer to the question is estimated by the teacher in the range from 1 to 5 points;

4. Test assessment of knowledge - 10 test tasks are given, each correct answer is estimated at 1 point, the maximum assessment is 10 points;

5. Evaluation of the performance of laboratory work the implementation and protection of laboratory work is estimated in the range from 1 to 8 points (for each task by 1 point).

\section{Discussion}

On the basis of the evaluation criteria presented in Table 1 , the formation of the competence of the organizers of the educational process of the Agrarian University in the use of ICT tools, the appropriate levels of competence are defined.

The low competence level of the organizers of the educational process at the Agrarian University using ICT means presupposes the availability of basic knowledge, skills and experience in the use of ICT facilities (knowledge of working with text editors, spreadsheets, e-mail and browsers, projection equipment).

The average level of competence presupposes the availability of knowledge, skills and experience in the use of ICT tools, allowing them to independently use these tools in organizational, managerial, technological, informational and analytical activities.

The high competence level of the organizers of the educational process at the Agrarian University using ICT means presupposes the availability of knowledge, skills and experience in the use of ICT tools, allowing to analyze, independently select and apply ICT tools for organizational, managerial, technological and informational and analytical activities. Including identify new methods for solving professional problems.

Formation of the competence of the organizer of the educational process of an agricultural university in the use of ICT facilities at the university can be determined on the basis of an assessment of the levels of knowledge, skills and experience in the use of ICT facilities in organizational, managerial, technological and informational and analytical activities.

\section{Conclusion}

The level of knowledge and skills of the listener in the use of ICT tools in their professional activities in organizing the educational process of an agricultural university can be assessed by the results of pedagogical testing. At the same time, test items must meet the following requirements: compliance with the objectives of training, validity, uniformity, and assessment of the correctness of each test task on the dichotomous measurement scale.

In accordance with these requirements, pedagogical tests consist of 30 test tasks. The correctness of them is evaluated according to the [0.30] -scale measurement scale, which, based on the approach was suggested by Bespalko V.P. [10], can be divided into 3 disjunctive subsets: $[0 ; 10],[11 ; 20]$ and $[21 ; 30]$. They correspond to a low, medium and high level of knowledge and skills in the use of ICT tools in organizational, managerial, technological and informational and analytical activities.

The level of experience the listener has in using ICT tools in their professional activities when organizing the educational process of an agricultural university can be assessed based on the results of the project assignment by the following components: experience in compiling a schedule of classes (organizational and management activities), experience in developing a presentation of a report (technological activity) and experience in analyzing the academic performance of the study group (information and analytical activities).

Evaluating each component on the [0.3] scale of the measurement, respectively, the scale of measurement of the results of the design task can be divided into three parts: [0-3] - with low, [4-6] - with average, [7-9] - with high levels of experience in using ICT tools in professional activities.

The level of formed competence of the organizers of the educational process at the Agrarian University in using ICT means corresponds to the lowest level of knowledge, skills and experience achieved by the student in the process of learning [11]. 
Table 1. Evaluation criteria for the competence formation of the organizers at the agricultural university using ICT

\begin{tabular}{|c|c|c|}
\hline $\begin{array}{c}\text { Evaluation criteria for the } \\
\text { development of competence in the } \\
\text { use of ICT tools }\end{array}$ & Measurable indicators & $\begin{array}{l}\text { Methods for measuring } \\
\text { indicators }\end{array}$ \\
\hline \multirow[t]{2}{*}{$\begin{array}{l}\text { The first criterion: } \\
\text { information search and mastering new } \\
\text { software products }\end{array}$} & $\begin{array}{l}\text { Ability to find, transmit educational information } \\
\text { produced using ICT tools }\end{array}$ & $\begin{array}{l}\text { Evaluation of how the } \\
\text { control task was } \\
\text { performed }\end{array}$ \\
\hline & $\begin{array}{l}\text { The ability to accept new software products, to } \\
\text { adapt their functions to the solution of } \\
\text { professional tasks, to judge the quality of the } \\
\text { representativeness of the software product }\end{array}$ & $\begin{array}{l}\text { Evaluation of how the } \\
\text { control task was } \\
\text { performed }\end{array}$ \\
\hline $\begin{array}{l}\text { The second criterion: the use of } \\
\text { technology for processing numerical } \\
\text { and textual information in the } \\
\text { educational process }\end{array}$ & $\begin{array}{l}\text { Willingness to develop and present the results of } \\
\text { educational research by means of tabular and } \\
\text { text editors }\end{array}$ & $\begin{array}{l}\text { Evaluation of students } \\
\text { independent work }\end{array}$ \\
\hline \multirow[t]{3}{*}{$\begin{array}{l}\text { The third criterion: } \\
\text { creation of didactic materials }\end{array}$} & $\begin{array}{l}\text { Ability to develop the structure of educational } \\
\text { didactic materials in accordance with the stage of } \\
\text { work in the project }\end{array}$ & $\begin{array}{l}\text { Evaluation of how the } \\
\text { control task was } \\
\text { performed }\end{array}$ \\
\hline & $\begin{array}{l}\text { The ability to develop and present teaching } \\
\text { materials by means of a text editor, to apply non- } \\
\text { standard, detailed teaching materials: } \\
\text { crosswords, quizzes, didactic cards, tests }\end{array}$ & $\begin{array}{l}\text { Evaluation of how the } \\
\text { control task was } \\
\text { performed }\end{array}$ \\
\hline & $\begin{array}{l}\text { The ability of students to substantiate their own } \\
\text { choice of text editor features for the presentation } \\
\text { of didactic materials }\end{array}$ & Oral poll of listeners \\
\hline \multirow[t]{2}{*}{$\begin{array}{l}\text { The fourth criterion: Creation of } \\
\text { Traditional Teaching Aids }\end{array}$} & $\begin{array}{l}\text { Ability to develop an educational and } \\
\text { methodological manual on the subject of your } \\
\text { project, where the material should be presented } \\
\text { taking into account ergonomic requirements }\end{array}$ & $\begin{array}{l}\text { Evaluation of how the } \\
\text { control task was } \\
\text { performed }\end{array}$ \\
\hline & $\begin{array}{l}\text { Ability to create layouts of teaching aids in the } \\
\text { editor of the creation of publications }\end{array}$ & $\begin{array}{l}\text { Evaluation of students } \\
\text { independent work }\end{array}$ \\
\hline \multirow{3}{*}{$\begin{array}{l}\text { The fifth criterion: methods of using } \\
\text { electronic educational resources on a } \\
\text { problem-modular basis (presentations } \\
\text { on the project topic) }\end{array}$} & $\begin{array}{l}\text { Knowledge of various types of electronic } \\
\text { educational resources }\end{array}$ & $\begin{array}{l}\text { Assessment of } \\
\text { knowledge through } \\
\text { testing }\end{array}$ \\
\hline & $\begin{array}{l}\text { Ability to create and use electronic educational } \\
\text { resources on a problem-modular basis }\end{array}$ & $\begin{array}{l}\text { Assessment of the } \\
\text { performance of } \\
\text { laboratory work }\end{array}$ \\
\hline & $\begin{array}{l}\text { Willingness to develop guidelines that reflect the } \\
\text { most important points of the project organization }\end{array}$ & $\begin{array}{l}\text { Evaluation of students } \\
\text { independent work }\end{array}$ \\
\hline \multirow[t]{3}{*}{$\begin{array}{l}\text { The sixth criterion: selection of } \\
\text { content for electronic educational } \\
\text { resources. }\end{array}$} & $\begin{array}{l}\text { The ability to own search methods in several } \\
\text { search engines and choose the optimal system to } \\
\text { solve a problem }\end{array}$ & $\begin{array}{l}\text { Evaluation of students } \\
\text { independent work }\end{array}$ \\
\hline & $\begin{array}{l}\text { The ability to save pages and links to resources } \\
\text { and make a brief annotation to the links }\end{array}$ & $\begin{array}{l}\text { Assessment of the } \\
\text { performance of } \\
\text { laboratory work }\end{array}$ \\
\hline & $\begin{array}{l}\text { Ability to structure and design materials required } \\
\text { for project execution }\end{array}$ & $\begin{array}{l}\text { Evaluation of students } \\
\text { independent work }\end{array}$ \\
\hline \multirow[t]{3}{*}{$\begin{array}{l}\text { The seventh criterion: the use of } \\
\text { presentation technology in the } \\
\text { organization of educational activities. }\end{array}$} & $\begin{array}{l}\text { The ability to apply in the layout of the } \\
\text { presentation of the author's design style, rather } \\
\text { than using ready-made templates }\end{array}$ & $\begin{array}{l}\text { Evaluation of students } \\
\text { independent work }\end{array}$ \\
\hline & $\begin{array}{l}\text { Ability to create a presentation on the research } \\
\text { topic (from the developer's point of view) }\end{array}$ & $\begin{array}{l}\text { Evaluation of students' } \\
\text { independent work }\end{array}$ \\
\hline & $\begin{array}{l}\text { Ability to conduct research according to a } \\
\text { system of independently defined goals and } \\
\text { objectives }\end{array}$ & $\begin{array}{l}\text { Evaluation of the } \\
\text { implementation of the } \\
\text { project task }\end{array}$ \\
\hline $\begin{array}{l}\text { The eighth criterion: the organization } \\
\text { of the virtual space of professional } \\
\text { activity. }\end{array}$ & $\begin{array}{l}\text { The ability to create a website using the program } \\
\text { to create publications and systematize the } \\
\text { materials included in the portfolio for } \\
\text { presentation on the site }\end{array}$ & $\begin{array}{l}\text { Evaluation of students' } \\
\text { independent work }\end{array}$ \\
\hline
\end{tabular}




\section{References}

1. A.R. Gazizov, E.R. Gazizov, Assessment of the Information and Technological Competence of the Administrative and Management Personnel of the University, Bulletin of South Federal University. Pedagogical sciences, 3, 97-102 (2013)

2. M.I. Kovalenko, Methodological aspects of increasing the qualification of teachers of older age in the field of information technology training, Pedagogical informatics, 4, 76-80 (2007)

3. O.A. Kozlov, Responsibilities of the employees of educational institutions in organizing the educational process using information and communication technologies, Informatics and education, 7, 8-21 (2008)

4. T.A. Lavin, Improving the system of continuous training of teachers in the use of information and communication technology in professional activities, dissertation (Moscow, 2006)

5. I.V. Robert, Philosophical-methodological, sociopsychological, pedagogical and technicaltechnological preconditions for the development of information education in the Russian language (IIO RAO, Moscow, 2008)
6. I.V. Robert, O.A. Kozlov, The concept of a comprehensive, multi-level and multi-disciplinary training of information education staff (IIO RAO, Moscow, 2009)

7. Federal state educational standards of higher professional education in the areas of training bachelors. The official website of the Coordination Council of educational and methodological associations and scientific and methodological councils of the higher school (Moscow, 2014) Retrieved from: http://fgosvo.ru/.

8. Official site of the Ministry of Labor and Social Protection of the Russian Federation (Moscow, 2014) Retrieved from: http://www.rosmintrud.ru/.

9. V.I. Petrova (2013) Criteria for assessing the degree of formation of ICT competence in the process of training future bachelors upon the "Pedagogical Education" program, Bulletin of Nizhnevartovsk state humanitarian university, 1, 59-63 (2013)

10. V.P. Bespalko, On the criteria for the quality of specialist training, Bulletin of the Higher School, 1, 3-8 (1988)

11. A.R. Gazizov, Methodical approaches to the formation of information technology competence of the organizers of the educational process of the agricultural university (as exemplified by advanced training), Author's abstract of dissertation (Moscow, 2013) 